\title{
Endangered WeSt AfRican Chimpanzees PAN tRoglodytes VerUS (SCHWARZ, 1934) (PRIMATES: HOMINIDAE) IN SENEGAL PREFER PTEROCARPUS ERINACEUS, A THREATENED TREE SPECIES, TO BUILD THEIR NESTS: IMPLICATIONS FOR THEIR CONSERVATION
}

\author{
Papa Ibnou Ndiaye ${ }^{1}$, Anh Galat-Luong ${ }^{2}$, Gérard Galat ${ }^{3}$ \& Georges Nizinski ${ }^{4}$
}

ISSN

Online 0974-7907

Print 0974-7893

${ }^{1}$ UCAD, Université Cheikh Anta Diop, Département de Biologie animale, B.P 5005, Dakar-Fann, Senegal

2,3 UCAD - IRD, Université Cheikh Anta Diop - Institut de Recherche pour le Développement, Département Ressources vivantes, and IUCN Species Survival Commission, Route des Pères Maristes, Dakar, Senegal

${ }^{4}$ IRD, Institut de Recherche pour le Développement, UMR 211 Bioemco, 5 rue du Carbone, 45072 Orléans cedex 2 ,

France

${ }^{1}$ ibnou.ndiaye@ucad.edu.sn (corrosponding author), ${ }^{2}$ anh.luong@ird.fr, ${ }^{3}$ gerard.galat@ird.fr, ${ }^{4}$ georges.nizinski@ird.fr

Abstract: The West African Chimpanzee Pan troglodytes verus is Endangered (A4cd ver 3.1) in Senegal (Humle et al. 2008), mainly due to habitat fragmentation and destruction. We gathered qualitative and quantitative data on the tree species preferences of the West African Chimpanzee for nest building in order to gain insight into habitat dependence. Between March 1998 and Febrary 2000 we identified tree species in which a sample of 1790 chimpanzee nests had been built, and ranked species in preference order. We compared this sample to the relative abundance of tree species in the chimpanzee habitat to determine whether particular species were chosen for nesting. We observed that about a quarter (25.42\%) of nests were built in Pterocarpus erinaceus, which is considerably greater than would be expected from the abundance of this species in the habitat (6.35\%), indicating a strong preference by chimpanzees. We examined the physical traits of the most-used tree species and concluded that height and wood hardness may be key choice features. P. erinaceus is threatened in Senegal due to extensive cutting, which may endanger chimpanzees living outside the boundaries of protected areas. In the current anthropogenic setting our results provide conservation managers with information on how to protect a key aspect of the chimpanzee natural environment.

Keywords: Chimpanzee, conservation, Pan troglodytes verus, Pterocarpus erinaceus, nest building.
Common Chimpanzee (Pan troglodytes Blumenbach, 1799) nest building behaviour has been reported by Nissen (1931), Bernstein (1962, 1967, 1969), Goodall (1962), Sabater Pi (1985), Wrogeman (1992), Barnett et al. (1994, 1996), Kortlandt (1996), Plumptre \& Reynolds (1997), Brownlow et al. (2001), and Basabose \& Yamagiva (2002) and more recently by Furnichi \& Hashimoto (2004), Hernandez (2006), Ogawa et al. (2007), Koops et al. $(2007,2012)$ and Stanfort \& O'Malley (2008). In Senegal, little data is published concerning the nest building behaviour of the West African Chimpanzee (Pan troglodytes verus Schwarz, 1934). Baldwin et al. (1981) collected information on nest heights, nest grouping, the number of nests per nest tree, the minimum distance between nests and nest tree trunk diameters in the Niokolo Koba National Park. At Fongoli, approximately $50 \mathrm{~km}$ southeast of Niokolo Koba National Park in southeastern Senegal, Stewart et al. (2007) studied

DOI: http://dx.doi.org/10.11609/JoTT.03603.5266-72 | ZooBank: urn:Isid:zoobank.org:pub:6948B88F-F433-4D34-AB50-9D6D9B4BF7B1

Editor: Jill Pruetz, lowa State University, Ames, USA

Date of publication: 26 December 2013 (online \& print)

Manuscript details: Ms \# 03603 | Received 30 April 2013 | Final received 11 November 2013 | Finally accepted 28 November 2013

Citation: Ndiaye, P.I., A. Galat-Luong, G. Galat \& G. Nizinski (2013). Endangered West African Chimpanzees Pan troglodytes verus (Schwarz, 1934) (Primates: Hominidae) in Senegal prefer Pterocarpus erinaceus, a threatened tree species, to build their nests: implications for their conservation. Journal of Threatened Taxa 5(17): 5266-5272; http://dx.doi.org/10.11609/JoTT.03603.5266-72

Copyright: (c) Ndiaye et al. 2013. Creative Commons Attribution 3.0 Unported License. JoTT allows unrestricted use of this article in any medium, reproduction and distribution by providing adequate credit to the authors and the source of publication.

Funding: This study was carried out and funded within the framework of the 'IPMO' and 'BIOEMCO' research programs of the French Institut de Recherche pour le Développement (IRD) and the University of Cheikh Anta Diop (Dakar, Sénégal).

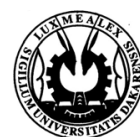

Competing Interest: The authors declare no competing interests. Funding sources had no role in study design, data collection, results interpretation and manuscript writing.

Acknowledgements: We would like to thank the directors, senior staff and agents of the Senegalese National Parks and Forestry for their kind collaboration, and we are also grateful to the inhabitants of Kédougou department for their warm welcome. We thank Yérémakan Keita, forestry technician at IRD, and local experienced rangers for help in plant species identification. Authors wish to thank also the anonymous reviewers and the Online Access to Research in the Environment (OARE) for facilitating literature. 
the comfort of chimpanzee nests on the basis of their physical features; Stewart \& Pruetz (2013) describe the anti-predator function of the nest. Pruetz et al. (2008) studied chimpanzees around Fongoli in comparison to those in the protected Niokolo Koba National Park to assess the anti-predator role of chimpanzee arboreal nest building behaviour, while also carefully detailing habitat structure and arboreal nest heights. However, there have been no published studies in which the plant species that chimpanzees use to build their nests were analysed.

The West African chimpanzee (Image 1) is listed as Endangered (A4cd ver 3.1) by IUCN (Humle et al. 2008). In Senegal, the main threats are habitat fragmentation/ destruction (Galat-Luong et al. 1999-2000; Carter et al. 2003; Humle et al. 2008) and competition with humans (Pruetz 2002). Additionally, some tree species used for woodworking, such as Pterocarpus erinaceus, are becoming hard to find outside of national parks (Brunken et al. 2008; author pers. obs.).

Galat-Luong et al. (1999-2000, 2009), Pruetz (2002), Pruetz et al. (2002), Carter et al. (2003) and Ndiaye et al. (2013) showed that chimpanzees still roam outside of their main refuge in Senegal, Niokolo Koba National Park. In this study we went outside of protected areas to gather and analyse the first qualitative and quantitative data on the West African Chimpanzee's tree species preferences for nest building in Senegal. Furthermore, we related these preferences to the availability of suitable trees in their habitat and to the features of preferred trees. These data are needed to provide

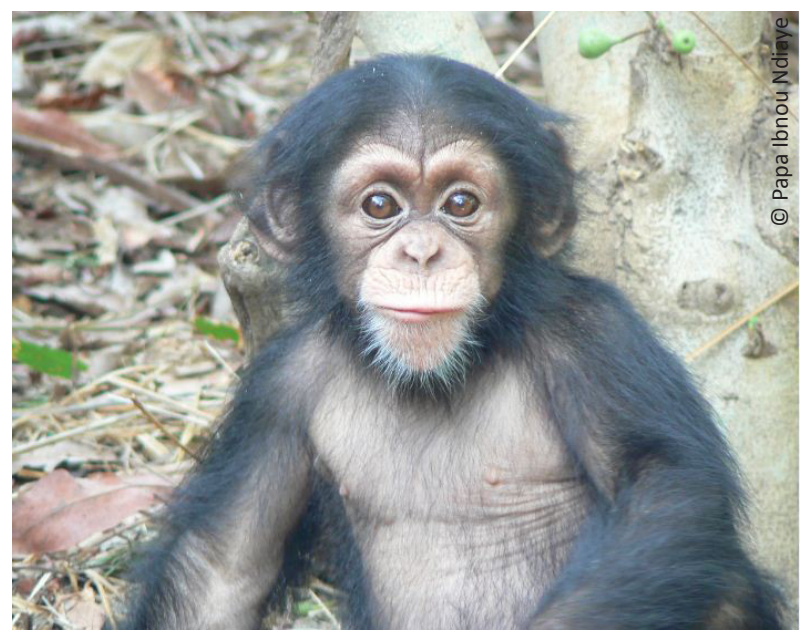

Image 1. West African Chimpanzee (Juvenile)

conservation managers with information on the extent of habitat dependency of this ape in Senegal and what consequences it may have in the anthropogenic setting currently characterizing this country.

\section{Methods}

Study Area: This study was carried out in Kédougou Region $\left(12^{\circ} 33^{\prime} \mathrm{N} \& 12^{\circ} 11 \mathrm{~W}\right)$ in southeastern Senegal (Fig. 1), in West Africa. See Pruetz et al. $(2002,2008)$ and Stewart \& Pruetz (2013) for detailed descriptions of the habitat vegetation types. We surveyed the entire region for chimpanzee habitats based on the presence of their nests. Annual rainfall in Kedougou over the 1995-1998 period ranged from 1000-1600 $\mathrm{mm}$, with one dry season

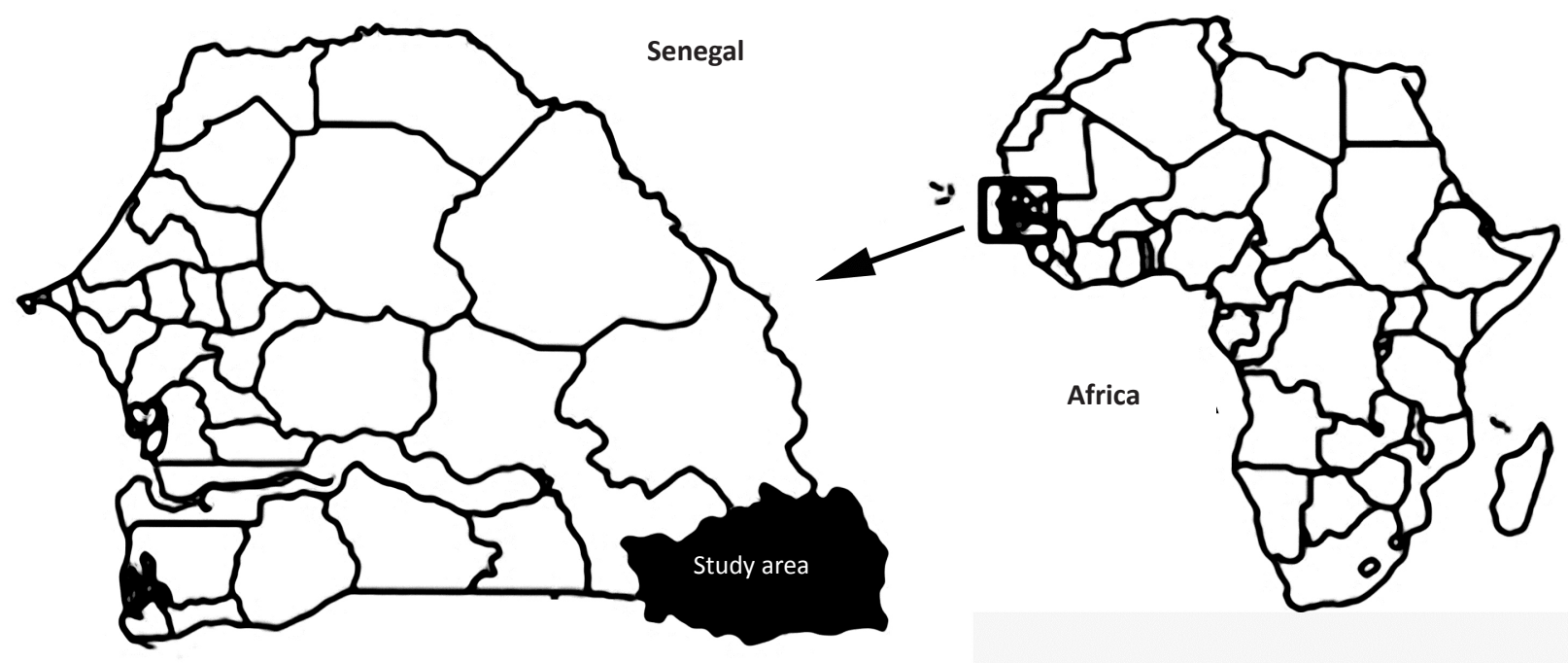

Figure 1. Location of the study area (modified from Ndiaye al. 2013). Detailed location of nests sites is available in Galat-Luong et al. (19992000). 
from October to May and one rainy season from June to September (Baldensperger 1965), which is typical of a Sudano-Guinean climate as defined by Aubreville (1949). The mean annual temperature was around $28.6^{\circ} \mathrm{C}\left(21.9-35.2^{\circ} \mathrm{C}\right)$ (Galat et al. 2009). Further details on the climate and its changes during this period and the impact on large fauna including chimpanzee behaviour were reported by Galat et al. (2009) and Galat-Luong et al. (2009).

Sudano-Guinean wooded savanna vegetation, as described by Aubreville (1949), prevails in this area. The tree densities vary, and open dry forests are sometimes found. Typically, Guinean tree species grow in gallery forests, which could be relicts of a former denser forest cover that diminished as a result of increasing dryness (Mühlenberg et al. 1990). Almost all trees shed their leaves during the long dry season, except for evergreens in gallery forests. The leaves usually re-emerge just prior to the first rains.

Nest trees: In a previous study (Galat-Luong et al. 1999-2000), in a 15,000km survey carried out in a vehicle, we first identified chimpanzee nesting sites in southeastern Senegal. The present study spanned over 80 days between March 1998 and February 2000, and we covered about $380 \mathrm{~km}$ outside protected zones on foot and recorded the number of chimpanzee nests on different species.

We identified plant species on the basis of the works of Berhaut (1967), Berhaut (1971-1979), Ferry et al. (1974), Maydell (1990), Choudens et al. (1995) and Ba et al. (1997), and with the contribution of a forestry technician from the French Institut de Recherche pour le Dévelopement, Dakar, and local experienced rangers.

Abundance of available trees in the habitat: We also sampled the availability in the habitat of tree species (and attached vines) that could potentially host chimpanzee nests by recording them along 927 sampling transects set up perpendicularly to the gallery forests along five rivers where chimpanzee nests had been recorded (Diaguiri River: 598 transects; Dimboli River: 130; Dialabatama River: 37; Djigoumato River: 56; and Linguékoto River: 106).

Species preferences for nest building: In order to assess tree species preferences for nest building, we compared the number of nests hosted by the different tree species to the abundance of the trees in the habitat using Fisher's exact test (two tailed).

\section{Results}

Nest trees: We sampled chimpanzee nests ( $N=1794)$ and found that only four had been built on the ground, while 1790 were built in trees. We identified the tree species bearing the nests (Table 1). Chimpanzees had built nests for resting in 34 different tree species.

Abundance of available trees in the habitat: We identified 834 trees and vines belonging to 44 different species (Table 1 ).

Species preferences for nest building: Some species were chosen proportionally to their abundance, whereas others were preferred or less preferred (Fisher's exact test $\mathrm{p}$-value significant to extremely significant; Table 1). Pterocarpus erinaceus, Parkia biglobosa, Anogeissus leiocarpus, Cola cordifolia, Erythrophylum guineensis, Ficus gnaphalocarpa, Lannea acida, Piliostigma reticulatum, and Dalbergia sissoo were used to a greater extent than their availability in the habitat would suggest.

Other tree species, including Syzygium guineense, Cordyla africana, Mitragyna inermis, Saba senegalensis, Dialium guineense, Bombax costatum, Terminalia macroptera, Grewia bicolor, Borassus aethiopium, Crateva religiosa, Nauclea latifolia, Acacia seyal, Bauhinia rufescens, Pterocarpus santalinoides, Daniellia oliveri, Lonchocarpus laxiflorus, Detarium microcarpum, Afrormosia laxiflora, Ziziphus mauritiana, and Ficus thonningii, were used less than expected for nesting. We did not find any statistical difference between nest use and availability in the habitat for the other tree species.

\section{Discussion}

Our results showed that chimpanzees in Senegal were highly selective when choosing trees in the environment to build their nests. Pterocarpus erinaceus was the most used by far: $25.42 \%$ of the nests were built in this species. This is four times more than expected by chance, given its relative abundance among trees in the habitat $(6.35 \%, \mathrm{p}<0.0001)$. In Issa, Ugalla, western Tanzania, chimpanzees also built their nests in a Pterocarpus species ( $P$. tinctorius Welw.) more often (184 of 1504 nests $=12 \%$ ) than would be expected considering the availability of this species in transect samples (8 of 211 trees $=4 \%$; Hernandez 2006). The second most used species, Diospyros mespiliformis, was chosen proportionally to its abundance. Chimpanzees feed on fruits of this tree, but ripe fruits were not always available (Ndiaye et al. unpub. data). Together with $P$. erinaceus, more than a third (36.82\%) of all nests were built in one of these two species. The three other species used most frequently, i.e., Parkia biglobosa (11.17\% of the nests), Anogeissus leiocarpus (9.22\%), and Cola cordifolia $(7.60 \%)$, were all highly selected $(p<0.0001)$. Nearly half (47.99\%) of all nests were recorded in the 
Table 1. Use of tree species by chimpanzees to build their nests.

\begin{tabular}{|c|c|c|c|c|c|c|}
\hline \multirow[t]{2}{*}{ Plant species } & \multicolumn{2}{|c|}{ Nest sample } & \multicolumn{2}{|c|}{ Tree sample } & & \multirow[b]{2}{*}{ p-value } \\
\hline & $\mathrm{Nn}$ & $\%$ & Nt & $\%$ & & \\
\hline Pterocarpus erinaceus Lam. & 455 & 25.42 & 53 & 6.35 & $<$ & 0.0001 \\
\hline Diospyros mespiliformis Hochst. & 204 & 11.40 & 101 & 12.11 & & 0.3056 \\
\hline Parkia biglobosa Benth. & 200 & 11.17 & 2 & 0.24 & $<$ & 0.0001 \\
\hline Anogeissus leiocarpus DC. Guill. \& Perr. & 165 & 9.22 & 21 & 2.52 & $<$ & 0.0001 \\
\hline Cola cordifolia Cav. R. Br. & 136 & 7.60 & 12 & 1.44 & $<$ & 0.0001 \\
\hline Syzygium guineense Willd. DC & 96 & 5.36 & 78 & 9.35 & & 0.0002 \\
\hline Cordyla africana Lour & 86 & 4.80 & 112 & 13.43 & $<$ & 0.0001 \\
\hline Erythrophlum guineensis G. Don. & 73 & 4.08 & 0 & 0.00 & $<$ & 0.0001 \\
\hline Khaya senegalensis A.Juss. & 63 & 3.52 & 32 & 3.84 & & 0.7364 \\
\hline Ficus gnaphalocarpa Steud. & 56 & 3.13 & 7 & 0.84 & $<$ & 0.0001 \\
\hline Mitragyna inermis (Willd.) K.Schum. & 45 & 2.51 & 48 & 5.76 & $<$ & 0.0001 \\
\hline Saba senegalensis (A.DC.) Pichon & 32 & 1.79 & 119 & 14.27 & $<$ & 0.0001 \\
\hline Lannea acida A.Rich. & 27 & 1.51 & 3 & 0.36 & & 0.0092 \\
\hline Dialium guineense Willd. & 24 & 1.34 & 32 & 3.84 & & 0.0001 \\
\hline Piliostigma reticulatum (DC.) Hochst. & 21 & 1.17 & 0 & 0.00 & & 0.0005 \\
\hline Piliostigma thonningii (Schumach.) Milne-Redh. & 17 & 0.95 & 19 & 2.28 & & 0.0105 \\
\hline Spondias mombin Jacq. & 16 & 0.89 & 24 & 2.88 & & 0.0002 \\
\hline Combretum glutinosum Jacq. & 12 & 0.67 & 12 & 1.44 & & 0.0755 \\
\hline Dalbergia sissoo Roxb. & 10 & 0.56 & 0 & 0.00 & & 0.0364 \\
\hline Ficus ingens Miq. & 8 & 0.45 & 0 & 0.00 & & 0.0619 \\
\hline Afzelia africana $\mathrm{Sm}$. & 7 & 0.39 & 1 & 0.12 & & 0.4487 \\
\hline Cassia sieberiana DC. & 7 & 0.39 & 6 & 0.72 & & 0.2477 \\
\hline Adansonia digitata $\mathrm{L}$. & 6 & 0.34 & 1 & 0.12 & & 0.4426 \\
\hline Combretum nigricans Leprieur & 6 & 0.34 & 0 & 0.00 & & 0.1858 \\
\hline Cordyla pinnata (A.Rich.) Milne-Redh. & 4 & 0.22 & 0 & 0.00 & & 0.3140 \\
\hline Guiera senegalensis Lam. & 4 & 0.22 & 0 & 0.00 & & 0.3140 \\
\hline Bombax costatum Pellegr. \& Vuillet & 2 & 0.11 & 5 & 0.60 & & 0.0367 \\
\hline Terminalia macroptera Guill. \& Perr. & 2 & 0.11 & 8 & 0.96 & & 0.0024 \\
\hline Butyrospermum parkii Kotschy & 1 & 0.06 & 3 & 0.36 & & 0.0977 \\
\hline Elaeis guineensis Jacq. & 1 & 0.06 & 3 & 0.36 & & 0.0977 \\
\hline Ficus dicranostyla Mildbr. & 1 & 0.06 & 1 & 0.12 & & 0.5347 \\
\hline Grevia bicolor Juss. & 1 & 0.06 & 5 & 0.60 & & 0.0142 \\
\hline Hexalobus monopetalus Engl. \& Diels & 1 & 0.06 & 0 & 0.00 & & 0.3178 \\
\hline Vitex doniana Sweet & 1 & 0.06 & 1 & 0.12 & & 0.5347 \\
\hline Borassus aethiopium Mart. & 0 & 0.00 & 27 & 3.24 & $<$ & 0.0001 \\
\hline Crateva religiosa Ainslie & 0 & 0.00 & 22 & 2.64 & $<$ & 0.0001 \\
\hline Nauclea latifolia Sm. & 0 & 0.00 & 20 & 2.40 & $<$ & 0.0001 \\
\hline Acacia seyal Delile & 0 & 0.00 & 10 & 1.20 & $<$ & 0.0001 \\
\hline Bauhinia rufescens Lam. & 0 & 0.00 & 10 & 1.20 & $<$ & 0.0001 \\
\hline Pterocarpus santalinoides L'Hér. & 0 & 0.00 & 9 & 1.08 & $<$ & 0.0001 \\
\hline Daniellia oliveri (Rolfe) Hutch. \& Dalziel & 0 & 0.00 & 5 & 0.60 & & 0.0032 \\
\hline Lonchocarpus laxiflorus Guill. \& Perr. & 0 & 0.00 & 4 & 0.48 & & 0.0102 \\
\hline Detarium microcarpum Guill. \& Perr. & 0 & 0.00 & 4 & 0.48 & & 0.0102 \\
\hline
\end{tabular}




\begin{tabular}{|c|c|c|c|c|c|c|}
\hline \multirow[t]{2}{*}{ Plant species } & \multicolumn{2}{|c|}{ Nest sample } & \multicolumn{2}{|c|}{ Tree sample } & & \multirow[b]{2}{*}{ p-value } \\
\hline & $\mathrm{Nn}$ & $\%$ & Nt & $\%$ & & \\
\hline Afrormosia laxiflora Harms & 0 & 0.00 & 3 & 0.36 & $<$ & 0.0001 \\
\hline Ziziphus mauritiana Lam. & 0 & 0.00 & 3 & 0.36 & $<$ & 0.0001 \\
\hline Ficus thonningii Blume & 0 & 0.00 & 2 & 0.24 & $<$ & 0.0001 \\
\hline Ficus polita Hort. & 0 & 0.00 & 1 & 0.12 & & 0.3178 \\
\hline Lannea microcarpa Engl. \& K.Krause & 0 & 0.00 & 1 & 0.12 & & 0.3178 \\
\hline Tamarindus indica L. & 0 & 0.00 & 1 & 0.12 & & 0.3178 \\
\hline Acacia macrostachya Rchb. & 0 & 0.00 & 1 & 0.12 & & 0.3178 \\
\hline Combretum micranthum G.Don & 0 & 0.00 & 1 & 0.12 & & 0.3178 \\
\hline Annona senegalensis Pers. & 0 & 0.00 & 1 & 0.12 & & 0.3178 \\
\hline Total & 1790 & & 834 & & & \\
\hline
\end{tabular}

$\mathrm{Nn}$ - Number of nests recorded on a same tree species; Nt - Number of trees of each species sampled in the habitat; \% - Percentage; p-value - Fisher's exact test p-value. Bold figures: significant to extremely significant.

three most used species, i.e., Pterocarpus erinaceus, $D$. mespiliformis and Parkia biglobosa.

Different authors have described selection of some tree species for nest building by chimpanzees, including Wrogemann (1992), Brownlow et al. (2001), Basabose \& Yamagiwa (2002), Hernandez (2006), Stewart et al. (2007) and Ogawa et al. (2007). According to Stanford \& O'Malley (2008), out of 163 tree species present in Bwindi National Park, Uganda, only four harboured $72.1 \%$ of all sampled chimpanzee nests. These authors noted the type of nest tree is influenced especially by the extent of food availability, safety and comfort (Stanford \& O’Malley 2008). Furnichi \& Hashimoto (2004) analysed different factors influencing nesting-site selection by chimpanzees in Kalinzu Forest, Uganda, where only four of seven preferred species provided edible fruit, and one of four less preferred species provided both edible fruit and leaves, the preference for certain species may not be explained by the availability of edible fruit or leaves in the preferred trees. Table 2 describes the physiognomic features common to the six most used tree species, which hosted $70 \%$ of all nests. These features, especially the wood hardness (which explains why they are regularly used by woodworkers), seemed to be associated with the chimpanzees' preferences. The sixth species, Syzygium guineense, though also hard, may have been less preferred $(5.36 \%$ of the nests versus $9.35 \%$ in the habitat, $p=0.0002$ ) because it was the smallest species.

Two other large tree species, which could be considered as being good 'nest hosts' due to their height, i.e., Butyrospermum parkii (syn. Vitellaria paradoxa, "Karité", "Shea") and Adansonia digitata, were not used more than expected $(0.06 \%$ and $0.34 \%$, respectively) given their abundance in the new habitat $(0.36 \%$ and $0.12 \%$, respectively, with no statistical significance). The common feature between these two tree species is their very soft and relatively poor quality wood. This also suggests that wood quality may be a chimpanzee nest tree selection criterion.

In this study, we noted a chimpanzee nest in an Elaeis guineensis Jacq tree on the edge of a gallery forest. Neither preference nor avoidance was significant $(p=0.0977)$. The nest was made of a single $E$. guineensis palm leaf even though several other tall trees, including Diospyros mespiliformis, were growing nearby. Gippoliti \& Dell'Omo (1995) also reported observing chimpanzee nests in E. guineensis trees in Guinea-Bissau. Moreover, Barnett et al. (1994) and Prangley \& Barnett (1994) observed a similar phenomenon on Mount Nimba in Guinea. Kortlandt (1996) reported observing chimpanzee nests in this species since 1965 in Guinea. All of these authors considered that nest building in $E$. guineensis trees is a typical behaviour of chimpanzees inhabiting West African degraded savanna forests, where the canopy is generally not closed. Two authors (A.G.L. \& G.G.) also observed that in Senegal E. guineensis trees were used as sleeping trees by Guinea baboons (Papio papio Desmarest 1820) along the Gambia River.

The high extent to which Pterocarpus erinaceus trees were used by chimpanzees for nest building should be emphasized. In West Africa and Senegal, this tree species is commonly used for fuel, woodworking and medicinal purposes (Lykke 2000; Karon et al. 2003; Brunken et al. 2008). As it is a highly valued fodder tree, pruning is a serious threat (Bonkoungou et al. 2001), and the species is declining and disappearing (Diallo 1997; Koita 1998). Furthermore, as the stumps generate few 
Table 2. Features of the six tree species most used by chimpanzees for nest building. From Ba et al. (1997) and supplemented.

\begin{tabular}{|c|c|c|c|c|}
\hline Species (Family) & Size & Foliation & Wood types and uses & $\begin{array}{l}\text { Wood- } \\
\text { working } \\
\text { index * }\end{array}$ \\
\hline Pterocarpus erinaceus (Fabaceae) & Tall, can grow above $15 \mathrm{~m}$ & After February and April & $\begin{array}{l}\text { Very hard, wood-working; } \\
\text { fuelwood }\end{array}$ & 1 \\
\hline Diospyros mespiliformis (Ebenaceae) & Tall, can grow above $20 \mathrm{~m}$ & Evergreen & Hard, wood-working; fuelwood & 1 \\
\hline Parkia biglobosa (Mimosaceae) & Tall, can grow to $20 \mathrm{~m}$ & $\begin{array}{l}\text { Leafless from November to January } \\
\text { (top generally parasol shaped) }\end{array}$ & $\begin{array}{l}\text { Hard, commonly used (highly } \\
\text { nutritional fruit) }\end{array}$ & 2 \\
\hline Anogeissus leiocarpus (Combretaceae) & Tall, can grow to $30 \mathrm{~m}$ & Leaves from January to March & Hard, wood-working; fuelwood & 1 \\
\hline Cola cordifolia (Sterculiaceae) & Tall, can grow to $30 \mathrm{~m}$ & Broad simple leaves, dense foliage & Hard, wood-working & - \\
\hline Syzygium guineense (Myrtaceae) & Short, can grow up to $12 \mathrm{~m}$ & Evergreen, tough fragrant leaves & $\begin{array}{l}\text { Hard, good fuelwood; hide } \\
\text { tanning }\end{array}$ & - \\
\hline
\end{tabular}

* Von Maydell (1992) woodworking quality index; 1 = excellent; 2 = medium, satisfactory; - = no available.

offshoots, regrowth is low and therefore regression is accelerated (Fournier et al. 2001). In addition, fallow shortening will lead to its extinction (Camara 1997). In Senegal, the species became so rare that logging, sawmills and woodworking companies had to stop exploiting this resource (P.I.N., pers. obs. and pers. com. of sawmill and woodworking company owners). As a result, though $P$. erinaceus is not registered on the IUCN Red List (but quantitative scientific data are lacking) as are the closely related species $P$. angolensis D.C. and $P$. brenanii L. Barb. \& Torre, (IUCN 2010), it is apparently threatened in Senegal.

In conclusion, chimpanzees were found to show preferences when choosing trees to build their nests. Pterocarpus erinaceus, a tree that is threatened in Senegal outside national parks due to abusive cutting and pruning, was found to be the tree species that chimpanzees most preferred for nest building, though its numbers have been drastically decreased. This choice is likely related to the hardness of its wood. There is a high risk that abusive cutting of $P$. erinaceus could endanger chimpanzees outside of protected areas where most of the population of Senegal's chimpanzees live. Consequently, chimpanzee conservation outside of such areas seems to be partly dependent on the preservation of this tree species. Moreover, in the habitat destruction and global climate change setting, chimpanzees will have to cope with increased flora changes. The results of the present work will provide conservation managers with information on how to protect the species' natural environment and to make appropriate management decisions.

\section{REFERENCES}

Aubreville, A. (1949). Climats, forêts et désertification de l'Afrique Tropicale. Société d'Editions Géographiques, Maritimes et Coloniales, Paris, 99pp.

Ba, A.T., B. Sambou, E. Finn, A. Goudiaby, C. Camara \& D. Diallo (1997). Végétation et Flore. Parc transfrontalier Niokolo Badiar. Projet Niokolo-Badiar FED 4213/REG - ISE. Dakar: Saint-Paul, 157pp.

Baldensperger, J. (1965). Etude pédologique d'un bassin versant de la région de Kédougou (Sénégal Oriental). ORSTOM. Dakar, 68pp.

Baldwin, P.J., J. Sabater Pi, W.C. McGrew \& C.E.G. Tutin (1981). Comparisons of nests made by different populations of chimpanzees (Pan troglodytes). Primates 22: 474-486; http://dx.doi.org/10.1007/ BF02381239

Barnett, A., M. Prangley, P. Hayman, D. Diawara \& J. Koman (1994). A preliminary survey of Kounounkan Forest, Guinea, West Africa. Oryx 28: 474-86.

Barnett, A., M. Prangley \& J. Koman (1996). Chimpanzee Pan troglodytes nest making behaviour in Guinea. African Primates 2: 22.

Basabose, A.K. \& J. Yamagiwa (2002). Factor affecting nesting site choice in Chimpanzees at Tshibati, Kahuzi-Biega National Park: Influence of sympatric Gorillas. International Journal of Primatology 23: 263-282; http://dx.doi.org/10.1023/A:1013879427335

Berhaut, J. (1967). Flore du Sénégal. Dakar: Clairafrique, 485pp.

Berhaut, J. (1971-1979). Flore illustrée du Sénégal. Ministère du Développement Rural et de I'Hydraulique Dakar. Sainte-Ruffine: L'imprimerie Maisonneuve S.A., 636pp.

Bernstein, I.S. (1962). Response to nesting materials of wild born and captive born chimpanzees. Animal Behaviour 10: 1-6.

Bernstein, I.S. (1967). Age and experience in Chimpanzee nest building. Southern Universities Press Psychological Reports 20: 1106.

Bernstein, I.S. (1969). A comparison of nesting patterns among the three great apes. The Chimpanzee 1: 393-402.

Bonkoungou, E.G., M. Djimdé, I. Zoungrana \& E. van Duij (2001). Trees in farm. Agroforestry to the disapearing fallow system in Sahel, pp. 714-720. In: Floret, C. \& R. Pontanier (eds.). La jachère en Afrique tropicale. Paris: John Libbey Eurotext.

Brownlow, A.R., A.J. Plumptre, V. Reynolds \& R. Ward (2001). Sources of variation in the nesting behavior of Chimpanzees (Pan troglodytes schweinfurthii) in the Budongo forest, Uganda. American Journal of Primatology 55: 49-55; http://dx.doi.org/10.1002/ajp.1038

Brunken, U., M. Schmidt, S. Dressler, T. Janssen, A. Thiombiano \& G. Zizka (2008). West African plants - A Photo Guide. Frankfurt/ Main: Forschungsinstitut Senckenberg. www.westafricanplants. senckenberg.de.

Camara, Y. (1997). Effet du raccourcissement du temps de jachère sur la régénération de Pterocarpus erinaceus en Haute Casamance 
(Sénégal). Diplôme d’Ingénieur des Eaux et Forêts, Ecole nationale des cadres ruraux de Djibelor, 48pp.

Carter, J., S. Ndiaye, J. Pruetz \& W.C. Mc Grew (2003). Sénégal, pp. 31-39. In: Kormos, R., C. Boesch, M.I. Bakaar \& T.M. Butynski (eds.). Status Survey and Conservation Action Plan: West African Chimpanzees. IUCN, Gland, Switzerland and Cambridge, UK.

Choudens, N., P.F. Delacharlerie \& M. Balde (1995). Lexique Peul / Latin des espèces végétales consommées par les Bovins. Lexique Peul / Français des résidus de culture consommés par les Bovins. Kolda: CIRAD - EMVT - ISRA - CRZ de Kolda, 48pp.

Diallo, M.S. (1997). Recherches sur l'évolution de la végétation sous l'effet de la pâture dans l'Ouest du Burkina Faso (zone soudanienne). Cas de Bondoukuy, Kassaho et Kourouma. Thèse $3 e$ cycle, sciences biologiques appliquées, biologie et écologie végétales, Université de Ouagadougou, 163pp.

Ferry, M.P., M. Gessain \& R. Gessain (1974). Ethno-botanique Tenda. Paris: Centre de Recherches Anthropologiques du Musée de I'Homme, Paris I. 178pp.

Fournier, A., C. Floret \& G-M. Gnahoua (2001). Végétation des jachères et succession post-culturale en Afrique tropicale, pp. 123-168. In: Floret, C. \& R. Pontanier (eds.), La jachère en Afrique tropicale. John Libbey Eurotext Paris.

Furnichi, T. \& C. Hashimoto (2004). Botanical and topographica factors influencing nesting-site selection by chimpanzees in Kalinzu forest, Uganda. International Journal of Primatology 25: 755-764; http://dx.doi.org/ 0164-029/04/0800-0755/0

Galat, G., A. Galat-Luong \& J.J. Nizinski (2009). L'impact du changement climatique sur les variations des populations de grands vertébrés à leur extrême limite de répartition est-il fonction de leurs régimes alimentaires? Geographia Technica, Numéro spécial: 355-360.

Galat-Luong, A., G. Galat, I. Ndiaye \& Y. Keita (1999-2000). Fragmentation de la distribution et statut actuel du Chimpanzé, Pan troglodytes verus, en limite d'aire de répartition au Sénégal. African Primates 4: 71-72.

Galat-Luong, A., G. Galat \& J.J. Nizinski (2009). En extrême limite nord de répartition, le réchauffement climatique a conduit les chimpanzés à filtrer leur eau de boisson. Geographia Technica, Numéro spécial: 199-204.

Gippoliti, S. \& G. Dell'Omo (1995). Status and conservation of the Chimpanzee Pan troglodytes verus in Guinea-Bissau. African primates 1: 3-5.

Goodall, J.M. (1962). Nest building behavior in the free - ranging chimpanzee. Annals of the New York Academy of Sciences 102 455-468.

Hernandez-Aguilar, R.A. (2006). Ecology and nesting pattern of Chimpanzees (Pan troglodytes) in Issa, Ugalla, Tanzania. PhD University of Southern California, Los Angeles.

Humle, T., C. Boesch, C. Duvall, C.M. Ellis, K.H. Farmer, I, Herbinger, A. Blom \& J.F. Oates (2008). Pan troglodytes ssp. verus. In IUCN 2010. IUCN Red List of Threatened Species. Version 2010.3. www. iucnredlist.org. Downloaded on 19 April 2013.

IUCN (2010). IUCN Red List of Threatened Species. Version 2010.4 <www.iucnredlist.org>, 2010, Downloaded on 28 April 2011.

Karon, D., M.H. Dicko, S. Sanon, J. Simpore \& A.S. Traore (2003). Antimalarial activity of Sida acuta Burn. F. (Malvaceae) and Pterocarpus erinaceus Poir. (Fabaceae). Journal of Ethnopharmacology 89: 291-294.

Koops, K., T. Humle, E.H.M. Sterck \& T. Matsuzawa (2007). Groundnesting by the chimpanzees of the Nimba Mountains, Guinea: Environmentally or socially determined? American Journal of Primatology 69 : 1-13; http://dx.doi.org/10.1002/ajp.20358

Koops, K., W.C. Mc.Grew, H. de Vries \& T. Matsuzawa (2012). NestBuilding by Chimpanzees (Pan troglodytes verus) at Seringbara, Nimba Mountains: Antipredation, Thermoregulation, and Antivector Hypotheses. International Journal of Primatology 33(2): 356-380; http://dx.doi.org/10.1007/s10764-012-9585-4

Koïta B. (1998). Végétation post-culturale en zone soudanienne au Sénégal. Influence des pratiques culturales et des facteurs anthropiques sur la reconstitution végétale après abandon cultural. Thèse Doctorat, Université Corse Pascal Paoli.

Kortlandt, A. (1996). Chimpanzee nest-making behaviour in Guinea and Uganda. African Primates 2: 80.

Lykke, A.M. (2000). Local perceptions of vegetation change and priorities for conservation of woody-savanna vegetation in Senegal. Journal of Environment Management 59: 107-120; http://dx.doi. org/10.1006/jema.2000.0336

Maydell, H.J.V. (1990). Arbres et arbustes du Sahel: leurs caractéristiques et leurs utilisations. Weikersheim: Josef Margraf Verlag.

Mühlenberg, M., A. Galat-Luong, P. Poilecot, B. Steinhauer-Burkart \& I. Kühn (1990). L'importance des îlots forestiers de savane humide pour la conservation de la faune de forêt dense. Revue d'Ecologie (Terre Vie) 45: 40-57.

Ndiaye, P.I., G. Galat, A. Galat-Luong \& G. Nizinski (2013). Note on the seasonal use of lowland and highland by the West African Chimpanzee Pan troglodytes verus (Schwarz, 1934) (Primates: Hominidae): Implications for its conservation. Journal of Threatened Taxa 5(2): 3697-3700; http://dx.doi.org/10.11609/JoTT. o3229.3697-700

Nissen, H.W. (1931). A field study of the chimpanzees: observation of chimpanzee behavior and environment in western French Guinea. Comparative Psychology Monographs 8: 1-22.

Ogawa, H., G. Idani, J. Moore, L. Pintea \& A. Hernandez-Aguilar (2007). Sleeping parties and nest distribution of chimpanzees in the savanna woodland, Ugalla, Tanzania. International Journal of Primatology 28: 1397-1412; http://dx.doi.org/10.1007/s10764007-9210-0

Plumptre, A.J. \& V. Reynolds (1997). Nesting behavior of chimpanzees: Implications for censuses. International Journal of Primatology 18: 475-485.

Prangley, M. \& A. Barnett (1994). A survey of primates in the Kounounkan Forest, Guinea, West Africa. Primate Eye 53: 14-17.

Pruetz, J.D. (2002). Competition between humans and Savanna Chimpanzees in southeastern Senegal. American Journal of Physical Anthropology, Supplement 34: 128; http://dx.doi.org/10.1002/ajpa. 20014

Pruetz, J.D., S.J. Fulton, L.F. Marchant, W.C. Mc Grew, M. Schiel \& M. Waller (2008). Arboreal nesting as anti-predator adaptation by Savanna Chimpanzees (Pan troglodytes verus) in southeastern Senegal. American Journal of Primatology 70: 393-401; http:// dx.doi.org/10.1002/ajp.20508

Pruetz, J.D., L.F. Marchant, J. Arno \& W.C. McGrew (2002). Survey of Savanna Chimpanzees (Pan troglodytes verus) in southeastern Senegal. American Journal of Primatology 58: 35-43; http://dx.doi. org/10.1002/ajp.10035

Stanford, C.B. \& R.C. O'Malley (2008). Sleeping tree choise by Bwindi chimpanzees. American Journal of Primatology 70: 642-649; http:// dx.doi.org/10.1002/ajp.20539

Stewart, F.A., J.D. Pruetz (2013). Do Chimpanzee nests serve an antipredatory function? American Journal of Primatology 75: 293-604; http://dx.doi.org/10.1002/ajp.22138

Stewart, F.A., J.D. Pruetz \& M.H. Hansell (2007). Do chimpanzees build confortable nests? American Journal of Primatology 69: 930939; http://dx.doi.org/10.1002/ajp.20432

Sabater, P.J. (1985). Etologia de la vivienda humana: de los nids de los gorillas y chimpances a la vivienda humana. Barcelona: Editorial Labor, S.A., $126 \mathrm{pp}$.

Wrogemann, D. (1992). Wild chimpanzees in Lopé, Gabon: census methods and habitat use. PhD. Bremen University, Bremen. 